\title{
Rental markets, gender, and land certificates: Evidence from Vietnam
}

\author{
Luciano Ayala-Cantu $^{\mathrm{a}, *}$, Bruno Morando ${ }^{\mathrm{b}}$ \\ ${ }^{a}$ Universidad de las Américas Puebla, Mexico \\ ${ }^{\mathrm{b}}$ Trinity College, Dublin, Ireland
}

A R T I C L E I N F O

\section{Keywords:}

Land use certificates

Land rental markets

Gender

Viet Nam

JEL classification:

JEL class

Q15

J16

\begin{abstract}
A B S T R A C T
In developing countries, a significant share of land transactions occurs among closely related parties and often does not entail any specific compensation (in-kind or monetary). Despite the prevalence of these non-market or informal transactions, the literature has paid little attention to the determinants and consequences of these exchanges. In this paper we shed light on the role land use certificates play on the agreed compensation of rental agreements when landlords, particularly those with weaker ex-ante tenure security (i.e. women), rent out land to their relatives in Viet Nam. We find that female-headed households who lease their plots to relatives are less likely to receive any type of payment, unless they possess a title for the plot they leased. A regional decomposition of our results shows that this effect is more predominant in the Northern regions.
\end{abstract}

\section{Introduction}

Weak enforcement of property rights has long been considered one of the key determinants of low agricultural productivity in developing countries. While many studies have focused on the tenure security channel (i.e. certainty of reaping the fruits of your work will incentivize long-term investment) another important mechanism through which property rights foster productivity is by allowing landholdings to be transferred to those better equipped to make productive use of them (e.g. via sales or rental markets). Several studies have documented the importance of well-functioning land markets for efficiency and equity in the rural sector (Skoufias, 1995; Banerjee et al., 2002; Holden et al. 2010; de Janvry et al., 2015; Chari et al., 2017; Chen et al. 2017).

Moreover, the literature has widely discussed the implications of gender differentials on property rights for agricultural productivity (Udry, 1996; Goldstein and Udry, 2008). Indeed, Agarwal (1995) argues that the single most important economic factor affecting women's situation in Southeast Asia is the gender gap in control and ownership of land. This inequality has crucial effects in the functioning of rental markets. In Ethiopia for example, Ghebru and Holden (2014) find that female landlords have lower yields in the plots they sharecrop with same-kin tenants. The authors suggest this is driven by opportunistic behaviour from tenants who, when kin is close, put less effort and inputs on sharecropped plots from women because the risk of eviction is lower.
In this paper we use the biennial Viet Nam Access to Resources Household Survey (VARHS) for the period 2008-2016 to explore the gender-specific impact of Land Use Rights Certificates (LUCs) on the choice of tenant and the compensation obtained by landlords in the rental market. Our results show that female-headed households that lease land to relatives are 25 per cent less likely to receive any type of compensation, unless they have a LUC for such plot. Our findings are robust to the endogeneity of plots getting titled within a household, and landlord's selection bias of tenant choice. One concern with informal land transfers is that compensation may not be directly stated, but it is implied and received through other channels (e.g. gifts or transfers). We corroborate this is not the case by showing that households renting their plots out for free do not receive more gifts or transfers from their relatives, even when affected by a negative shock. Moreover, we present a regional decomposition of our empirical analysis and we find that our results are being mostly driven by the dynamics of rental markets in the North of Viet Nam.

Furthermore, we explore the impact of these non-market land rentals on agricultural productivity and household income. Our findings show that farmers who receive land for free are systematically less productive than those who pay for it. This suggests that non-compensated land transactions might be less efficiency enhancing than those that are market based. Moreover, households engaging in non-market transactions give up on average 5 percent of their income due to these informal transactions.

This paper contributes to the literature in two ways. First, as far as we know, this is the only study showing the relationship between

\footnotetext{
* Corresponding author.

E-mail address: luciano.ayala@udlap.mx (L. Ayala-Cantu).
} 
property rights and agreed compensation in rental markets, particularly in the case of groups with weaker ex-ante tenure security (i.e. women). Second, this is the first study of land rental markets in Viet Nam that explicitly distinguishes between formal and informal transactions. ${ }^{1}$ This is surprising given that informal transactions represent more than half of the land rentals in the country. Additionally, our regional analysis provides insights on how policy changes in land tenure are likely to have a more significant impact in the Northern provinces of Viet Nam, where social institutions and attitudes towards market-oriented policies are considerably different than in the South.

The findings of this paper are useful to orient agricultural policies in the developing world. First, it highlights the importance of taking into account ex ante property rights enforcement for vulnerable groups (women, in our case) when undertaking a land tenure reform. Second, it sheds light on the effect that informal land transfers can have on agricultural productivity and income of poor landlords. Lastly, the regional decomposition of our findings shows the importance of considering pre-existing institutions and norms before implementing structural reforms that seek to modify such arrangements.

The structure of the paper is as follows: in Section 2 we outline our conceptual framework, in Section 3 we describe the land reforms undertaken in Viet Nam and their implications for women's land rights. The data and some descriptive statistics are presented in Section 4. In Section 5 we discuss the estimation strategy we employ to test our hypotheses and in Section 6 we present our results. In Section 7 we conclude with some final remarks.

\section{Conceptual framework}

The literature discusses two main reasons a landlord may decide to participate in land rental markets. First, as an economy advances in the process of economic development, opportunities in the non-agricultural sector will improve. This will trigger a process of structural transformation where rural households with a comparative advantage in nonfarming activities will leave agriculture to pursue more attractive opportunities in other industries (Duarte and Restuccia, 2010). ${ }^{2}$ Second, a low endowment of non-land agricultural factors of production (e.g. labour) drives landowners to lease out their property for income generation. We think the latter framework is what best describes the behaviour of female landlords. Though in theory women could just hire workers until they reach their optimal farm scale, agricultural labour markets have high costs of monitoring and enforcing effort (Feder, 1985). Moreover, these costs are likely to be higher for women since tradition in Viet Nam dictates farming decision should be taken by men (Tran, 2001). ${ }^{3}$

${ }^{1}$ Khai et al. (2013) show that generally land obtained through rental or sale markets is operated by more productive farmers than plots allocated by local authorities in Viet Nam, but they do not study the difference between formal and informal temporary land transfers.

${ }^{2}$ Estimations from the 2009 population census in Viet Nam reveal that the annual rate of migration within provinces, mostly from the countryside to cities, increased from 0.6 percent in 1999 to 4.2 percent in 2009 (Narciso, 2017). Moreover, rural households with higher welfare tend to substitute agricultural activities with wage labour and entrepreneurial activities (Kinghan and Newman, 2017).

${ }^{3}$ Also male-headed households who lease out land are better off than maleheaded households that do not; their income levels are 42 percent higher than other male-headed households that do not rent out land. The opposite is true for female landlords, as they have 6 percent less income than other female-headed households. This suggests that the factors determining rental market participation differ crucially depending on the gender of the household head. While men decide to participate in rental markets because it allows them to pursue opportunities outside agriculture and improve their incomes, female landlords tend to rent out land because they are too old to farm it and lack the resources to do it properly (female-headed households have fewer household members, less capital and are considerably older).
Despite the potential benefits of land markets, participation in land rentals faces considerable challenges. Weak enforcement of property rights increases the risk of losing your land when it is rented out, discouraging potential landlords from participating in rental markets (Besley and Ghatak, 2010). Also, tenure insecurity can influence landlord's choice of tenant and rental arrangement in the market. In Madagascar, Bellemare (2012) finds that landlords with a lower perceived tenure security were more likely to engage in sharecropping contracts instead of fixed rents because participating in the production process increases the landlord's claims to the land (land-to-the-tiller agricultural system). In the Dominican Republic, Macours et al. (2010) find that tenure insecurity and weak contract enforcement leads landlords to operate along similar socio-economic lines, which comes with significant detrimental effects on efficiency and equity.

The imperfections in rental markets are more likely to disproportionally affect female landowners, since they normally have weaker property rights (Agarwal, 1995; Menon et al., 2017). Evidence from Ethiopia shows that female landlords have lower productivity in the plots they sharecrop, compared to male landlords. Holden and Bezabih (2008) suggest the reason for this gender differential could be that women may be forced to rent land to in-laws as opposed to the best (and presumably most productive) bidder. This results not only in an overall efficiency and productivity loss, but also in a worse outcome for the landlord that might not be able to receive fair compensation. Land titles can be an efficient mechanism to correct this kind of distortions. In Ethiopia, Holden et al. (2011) find that a low-cost land certification program had a relatively larger effect on women's participation in rental markets.

In this paper we want to understand the relationship between property rights and landlord's choice of tenant and agreed ex-ante compensation for the land transaction. If land certificates strengthen landlord's property rights, we would expect that households who have their plots titled-especially those with weaker ex-ante tenure security-would obtain better compensations in the rental market. This is because with the improvement in property rights, landlords no longer fear expropriation when renting out to non-related parties, so they can chose from a wider pool of possible tenants. Consequently, their bargaining power increases, so even if they ultimately decide to lease to a relative, such rental agreement would be conducted under better circumstances for the landlord. If women have weaker ex-ante tenure security, then the effect of land certification on the probability to obtain compensation for the land rented out to relatives should be larger for female landowners.

\section{Background: Land tenure and gender in Viet Nam}

During the 1980s Viet Nam started a de-collectivization process in its agricultural sector to form a production system based on household initiative. Before the reforms took place, agricultural production was carried out collectively and farmers were compensated by the hours they worked. However, after facing severe food shortages at the beginning of the 1980s, the government implemented a new policy in which farmers were responsible for delivering a quota to the commune and allowed them to keep or sell any surplus. ${ }^{4}$ With the implementation of the Doi Moi reforms in 1988, the government addressed some concerns regarding tenancy security and started the privatization and decentralization of output and input markets (but land market transactions remained illegal).

In 1993, a new land law was enacted to transfer private usage rights to rural households. Though the land remains the property of the State, households received land use certificates (LUCs) that allow them to

\footnotetext{
${ }^{4}$ These reforms had a positive and significant effect on rice production (Pingali and Xuan, 1992).
} 
transfer, lease, mortgage and bequest the usage rights of their land. ${ }^{5}$ The land certification program was one of the most extensive in the world: by the year 2000 the Vietnamese government had issued more than 11 million certificates, granting land titles to more than 90 percent of rural households (Do and Iyer, 2008). However, the implementation of the land reform had important regional differences and land certification has failed to increase in the last decade (Markussen, 2017).

Do and Iyer (2008) argue that the General Department of Land Administration (GDLA) faced two main challenges in the implementation of the reform: lack of manpower in commune land registry offices and the time taken to resolve disputes related to land ownership. The heterogeneity of administrative capacity of provinces resulted in very different speeds of land certification. For example, the authors see that the proportion of households with LUCs in 1998 varied from 12 percent to 100 percent across different provinces, and that in 2000 five provinces have failed to achieve coverage in more than 75 percent of the households in the province.

More recent data suggests land certification still faces challenges in some regions; according to our sample, in the Mekong River Delta almost all plots have a LUC, while in the Central Highlands titling is least prevalent. Even among the Northern provinces we observe significant differences; in Phu Tho, a relatively rich province in the north, more than 90 percent of plots have titles while the highland provinces of Dien Bien and Lai Chau have less that 40 percent of their plots titled. Markussen (2017) says that one of the reasons why land titling has stayed constant in the last decade could be informal fees or corruption in the land administration system. ${ }^{6}$ Also, the Governance module of the 2008 Viet Nam Household Living Standards Survey (VHLSS) reports that 55 percent of rural households perceive that the process of LUC issuance is affected by corruption in local governments (World Bank, 2009, ch. 3).

The 1993 Land Law increased agricultural investment and allowed households to pursue non-farming activities (Do and Iyer, 2008). According to Deininger and Jin (2008) the legalization of land usage transfers increased efficiency and allowed poor households to access land as the non-agricultural sector of the economy evolved. ${ }^{7}$ Moreover, the prevalence of State allocations has been gradually substituted by transfers among individual households, resulting in sizeable productivity gains (Khai et al., 2013). ${ }^{8}$ Despite the apparent consensus on the benefits of Vietnam's land reforms, others have argued that the land laws aggravated inequality and created a growing class of landless citizens (e.g. Akram-Lodhi, 2005). Such claims have also been made from the perspective of gender inequality in access to land.

Menon et al. (2017) argue that some features of the 1993 land reform in Viet Nam exacerbated gender disparities in property rights. For example, the law allowed for only one name to be in the certificate as the sole owner of the land; in most cases the man-being the head of the household-had his name registered in the title. Also, the

\footnotetext{
${ }^{5}$ The duration of use rights was set at 20 years for annual crops and 50 years for perennial crops. However an amendment to the Land Law in 2013 set the duration of use rights to 50 years for all types of crops.

${ }^{6}$ We would expect this kind of restrictions to be more binding for vulnerable households. Indeed, Markussen and Tarp (2014) show that political connections are positively related to increase land tenure security and investment.

${ }^{7}$ A proper functioning of land markets is essential for a smooth readjustment of labour from agriculture to other industries (Adamopoulos et al., 2017). This process is particularly important in Viet Nam since the share of the labour force devoted to agriculture decreased from 70 per cent in 1996 to 44 per cent in 2015 (ILOSTAT, 2017).

${ }^{8}$ Vietnam and other post-socialist economies have traditionally relied on administrative reallocation of land instead of markets. However, evidence from China suggests that though reallocations assign land to households with low land endowments and numerous families, markets are a better mechanism since they ultimately assign the land to farmers with higher ability (Deininger and Jin, 2005; Kimura et al., 2011).
}

certification was granted at the farm level instead of the plot level (which could have allowed for some differentiation in asset ownership between husbands and wives). Finally, the authors mention that some of the guidelines in the land redistribution process favoured men over women, and this inequality was worsened by social norms and cultural traditions in which farm production decisions were made primarily by men (Tran, 2001). ${ }^{9}$ Between 2000 and 2003 a series of legislative changes were conducted to address this gender disparity. The Marriage and Family Law of 2000 declares that any LUC obtained during the course of the marriage should be counted as common property (i.e. have both names in the title). Moreover, an amendment to the Land Law in 2003 indicates that certification has to be carried out at the plot level, which allows a legal differentiation in asset ownership for both husband and wife. ${ }^{10}$ Nonetheless, some have argued that the implementation of these changes has not been properly enforced because of lack of administrative capacities in rural agencies (Ravallion and van de Walle, 2008; World Bank, 2002).

The land tenure system in Viet Nam -unlike China and other African countries- is not characterized by extensive land reallocations or expropriations, and the land reforms undertaken in the past decades have come a long way in improving tenure security. ${ }^{11}$ Nonetheless, it is still possible that gender differences in land rights affect the functioning of rental markets, particularly when the transactions happen among relatives. In our sample, more than half of the plots that were rented out did not lead to any compensation for the landlord (monetary or in-kind) and more than two thirds of the rentals occurred among relatives. ${ }^{12}$ The prevalence of such a high level of informal transactions raises concerns because it could be a reflection of property rights imbalances among households, as those with weaker claims over land may fail to receive adequate and fair compensation.

\section{Data and descriptive statistics}

The empirical analysis will be based on the Viet Nam Access to Resources Household Survey (VARHS), covering the period 2008-2016. The VARHS is conducted every two years and is a representative sample of the rural population in Viet Nam. We rely on the balanced panel sample which consists of 2131 rural households that were surveyed in all the five waves collected in the period under analysis. The surveyed households are located in 476 communes across 12 different provinces. The dataset contains precise information on household demographics, economic activities, land use and agricultural production. Crucially, the survey contains detailed plot-level characteristics and information on land rental agreements (e.g. relationship to the tenant, type of contract and agreed payment).

In Table 1 , we provide descriptive statistics of the main variables

\footnotetext{
${ }^{9}$ For example, the age of the household head and the number of household members in working age were considered for the amount of land allocated, given that the legal retirement age for women is 55 and for men 60 and femaleheaded households tend to have fewer working-age members, women tend to receive less land than men.

${ }^{10}$ Newman et al. (2015) say that, conditional on the plot having a certificate, registering the plot under two names as opposed to one does not affect productivity. They argue that including both names in the certificate could be a useful policy to increase women's bargaining power within the household, since there is no trade-off between productivity and including two names in the certificate instead of one. Menon et al. (2017) find that land-use rights held exclusively by women or jointly by couples result in higher household expenditures, more women's self-employment and lower household vulnerability to poverty.

${ }^{11}$ In our data, only around two percent of the plots were expropriated by commune authorities in a given year.

${ }^{12}$ Virtually all of the contracts contemplating some sort of compensation have the form of fixed rent. Therefore, we will now only distinguish between rental contracts with and without compensation, regardless of the type of payment arrangement (fixed rent or sharecropping).
} 
Table 1

Household level characteristics (means) by gender of the household head. Source: Authors' computation from VAHRS data.

\begin{tabular}{llll}
\hline Variable & $\begin{array}{l}\text { Female- } \\
\text { headed }\end{array}$ & $\begin{array}{l}\text { Male- } \\
\text { headed }\end{array}$ & $\begin{array}{l}\text { p-value } \\
\text { difference }\end{array}$ \\
\hline Education of household head (years) & 7.68 & 8.37 & 0.00 \\
Age of household head (years) & 61.27 & 52.58 & 0.00 \\
No. of household members & 3.49 & 4.52 & 0.00 \\
No. of men in working age & 0.93 & 1.62 & 0.00 \\
No. of women in working age & 1.12 & 1.40 & 0.00 \\
No. of draft animals & 0.33 & 0.70 & 0.00 \\
Land owned (thousand sqm) & 3.43 & 7.04 & 0.00 \\
Land Farmed (thousand sqm) & 3.38 & 7.20 & 0.00 \\
No. of non-farm activities & 0.24 & 0.33 & 0.00 \\
Income per capita (thousand VND) & 21.27 & 22.14 & 0.14 \\
Assets per capita (thousand VND) & 7.00 & 13.26 & 0.28 \\
Proportion of land with LUC & 0.78 & 0.73 & 0.00 \\
Proportion of households renting out land & 0.21 & 0.16 & 0.00 \\
Percentage of land rented out* & 0.76 & 0.68 & 0.00 \\
Percentage of land rented out to relatives* & 0.70 & 0.65 & 0.04 \\
Percentage of land rented out for free* & 0.44 & 0.54 & 0.00 \\
Percentage of land rented for free conditional & 0.85 & 0.79 & 0.04 \\
$\quad$ on being rented out to relatives* & & & \\
N & 2388 & 8267 & -
\end{tabular}

The mean statistics are computed using the 5 waves (one every two years) of the balanced household panel. This includes 2,131 observations across 5 time periods.

*This proportion is calculated conditional on the household renting out some land. There are 1824 observations in this sub-sample (approximately 17 per cent of the full sample). From 2008 to 2016, the number of households renting land out has increased from 13 to 20 percent. More than 76 percent of these temporary land transfers have occurred among relatives and/or without any type of compensation (monetary or in-kind).

used in the analysis by gender of the household head. Drawing from the entire five-wave sample, we observe that female household heads tend to be less educated and older; they also have fewer members, and in particular fewer men and women in working age. As far as agricultural inputs are concerned, they also own less land and draft animals. In light of that, it is hardly surprising that male-headed households have higher levels of income and assets per capita. However, such differences are not statistically significant at any conventional level.

These simple figures highlight some interesting facts about land rental behaviour. First of all, despite having significantly lower land endowments, women are more likely to rent some agricultural plots out: 21 percent of female-headed households rent out land compared to 16 percent of male-headed households. ${ }^{13}$ When women lease out land, they tend to rent a higher proportion of their total holdings. There are also some significant differences in the choice of tenants and type of rental agreement: female landlords are more likely to rent their land to relatives and not to receive any compensation when they do. However, at an unconditional level, male landlords tend to give a higher proportion of their leased land for free. ${ }^{14}$ Moreover, female-headed households have a higher fraction of their land certified. The main objective of the empirical analysis will be to assess how these certificates affect their decisions concerning the rental market.

As mentioned above, our dataset contains several plot level

\footnotetext{
${ }^{13}$ This is possibly because women also possess fewer resources to conduct agricultural production (i.e. household members of working age and draft animals).

${ }^{14}$ The data we have tells us the monetary value of the rental agreement, whether the tenant pays cash or in some other way (part of the harvest for example). In the case of an in-kind payment, landlords give an estimated value of the compensation they receive. Hence, if landlords report they received zero compensation for the rental transaction, this means they did not receive money or anything else in exchange for leasing the land.
}

Table 2

Plot level characteristics by certification status. Source: Authors' computation from VAHRS data.

\begin{tabular}{|c|c|c|c|}
\hline & $\begin{array}{l}\text { No LUC } \\
\text { (mean) }\end{array}$ & LUC (mean) & $\begin{array}{l}\text { p-value } \\
\text { difference }\end{array}$ \\
\hline \multicolumn{4}{|l|}{ Full Sample } \\
\hline Area (log sqm) & 6.77 & 6.29 & 0.00 \\
\hline Restrictions & 0.34 & 0.51 & 0.00 \\
\hline Fertility $(1=$ low $3=$ high $)$ & 1.94 & 1.95 & 0.00 \\
\hline Irrigation & 0.65 & 0.84 & 0.00 \\
\hline Annual crops & 0.86 & 0.90 & 0.00 \\
\hline Slope $(1=$ flat $4=$ very steep $)$ & 1.66 & 1.30 & 0.00 \\
\hline Bordering another plot $(1=$ yes $)$ & 0.10 & 0.14 & 0.00 \\
\hline Distance from home (log m) & 6.68 & 6.09 & 0.00 \\
\hline $\mathrm{N}$ & 9355 & 28517 & \\
\hline \multicolumn{4}{|l|}{ Plots Rented out } \\
\hline Area (log sqm) & 5.95 & 5.92 & 0.56 \\
\hline Restrictions & 0.61 & 0.53 & 0.00 \\
\hline Fertility $(1=$ low $3=$ high $)$ & 1.98 & 1.99 & 0.69 \\
\hline Irrigation & 0.87 & 0.87 & 0.69 \\
\hline Annual crops & 0.97 & 0.96 & 0.24 \\
\hline Slope $(1=$ flat $4=$ very hilly $)$ & 1.20 & 1.16 & 0.01 \\
\hline Bordering another plot & 0.08 & 0.11 & 0.01 \\
\hline Distance from home (log m) & 6.38 & 6.37 & 0.93 \\
\hline Rent out to relative & 0.66 & 0.66 & 0.71 \\
\hline Rent out for free & 0.60 & 0.50 & 0.00 \\
\hline $\mathrm{N}$ & 3399 & 980 & \\
\hline
\end{tabular}

characteristics which we will include in our empirical analysis to control for factors that might affect both the decision to obtain a certificate and the compensation received when the plot is rented out. Some descriptive statistics for these variables are presented in Table 2 for the full sample of plots, as well as for those that were rented out.

According to the full sample, certified plots appear to be on average of better quality than non-certified ones. More specifically, they have higher (self-reported) fertility, are more likely to be irrigated, flatter and closer to the farmers' homestead. They are also more likely to be restricted to rice production and this would explain why are also more likely to be cultivated with annual crops. It is important to stress that since the majority of households have either all or none of their plots certified (only in 10 percent of the household observations we see titled and un-titled land), these differences most likely represent variations in land characteristics across households rather than plot-level differences within households.

These differences are however less pronounced in the subsample of plots rented out. In this case, plots with and without certification have on average the same fertility and irrigation levels, and are equally distant from the farmers' dwellings (although certified plots are more likely to be sharing a border with another household plot). The sole measure of land quality that presents a statistically significant difference in mean is the slope, as certified plots are shown to be on average flatter. In terms of the choice of tenant, we were not able to identify any significant difference: certified and non-certified plots are equally likely to be rented out to relatives. However, certified plots are less likely to be leased out for free.

\section{Estimation strategy}

The goal of this paper is to assess whether land certificates increase the probability of receiving some compensation when a plot is rented to relatives and if the impact is stronger for female-headed households. We focus on the landowners that rent land to their relatives-which represent almost two thirds of all temporary land transfers-because these contracts are more likely to be influenced by social norms and the relative bargaining power between landlords and tenants. If certificates strengthen landlord's property rights, we would expect that households who have their land titled-especially those with weaker ex-ante tenure security-are more likely to receive compensation for the land they rent 
because they can choose from a wider pool of possible tenants and have a stronger position in the negotiation process of the contracts. The first specification we estimate takes the following form:

$$
\begin{aligned}
\operatorname{Pr}\left(\text { Free }_{p h t}\right)= & \beta_{1} \text { Female }_{h t}+\beta_{2} \text { LUC }_{p h t}+\beta_{3} \text { Female }_{h t} * L U C_{p h t}+X_{h t}^{\prime} \gamma \\
& +Z^{\prime}{ }_{p h t} \delta+\tau_{t}+\zeta_{c}+\varepsilon_{p h t}
\end{aligned}
$$

where the probability of a plot being rented out for free (conditional on being rented out to a relative) is modelled as a linear function of the gender of the household head, whether the owner has a land use certificate for the plot, their interaction term, a set of household (X) and plot $(Z)$ level characteristics, and time and commune fixed effects. ${ }^{15}$ The estimate of $\beta_{1}$ would indicate whether female-headed households are less likely to receive compensation for the plots they rent out, the sign of $\beta_{2}$ would tell us if the LUC plays a role in the probability of renting land for free (regardless of the landlord's gender) and a negative and significant estimate of $\beta_{3}$ would corroborate the hypothesis that LUCs have a gender-differential impact, increasing the probability of female-headed households to obtain some payment when leasing out land to their relatives.

In the specification described so far, the outcome of receiving or not compensation for the land transferred is observed within a restricted sample: the landlords that decided to transfer land to a relative. ${ }^{16}$ Hence, we are excluding all the transactions between non-relatives, which ignore landlord's first level decision-renting to a relative versus renting to someone else. Such restriction can lead to problems of selection bias if there are some unobservable factors that are affecting both the choice of tenant and whether any compensation is received. We address this concern following the two-step procedure suggested by Ahn and Powell (1993). ${ }^{17}$ The first step consists in estimating non parametrically the conditional mean of the probability of each rented out plot to be given to a relative, while in the second step this index is added non parametrically as a control in the regression of interest, otherwise identical to Eq. (1). ${ }^{18}$

\footnotetext{
${ }^{15}$ The household level variables included in the regression are: age and years of education of the household head, number of individuals in working age, number of draft animals owned, total value of the durable goods (log), a dummy indicating whether the head of the household belongs to a ethnic minority, another dummy taking value 1 when the household has experienced a natural shock, and finally household's income decile. The plot level characteristics are the area (in logs), whether the land is planted with annual or permanent crops, if there is an irrigation system and whether there are restrictions on the crops that have to be grown. Finally, we include some selfreported indexes of land quality ( 1 = below average 2 = average 3 = better than average) and terrain roughness ( $1=$ flat to $4=$ very steep).

${ }^{16}$ Unfortunately, our data does not allow us to know the kind of relationship between landlords and tenants (if it is their children, siblings, cousins, and so on).

${ }^{17}$ For some (Dubois, 2002), another important potential source of endogeneity comes from the decision of landowners to become landlords instead of cultivating their land. This paper does not model the decision to rent out land, and instead focuses on the relationship between rental payments and property rights, conditional on the farmer having decided to become a landlord. Consequently, our findings are only valid for the subsample of the landowner population that selects themselves into landownership. However, if non-observed factors that drive the decision to become a landlord are also correlated with the probability of receiving rent when leasing out to a relative, our estimates could be biased. This is a problem which we cannot address directly, so our results are meant to be taken as illustrative of the importance that LUCs have for female-headed households who participate in land rental markets, and not an implication of the causal relationship between property rights and rental market participation.

${ }^{18}$ In particular, the expected probability of renting each plot to relatives (conditional mean) is estimated in the first step using the kernel estimator. The second step is a semi-parametric regression where we do not impose any functional form to the impact of the conditional mean estimated in the first step on the probability of receiving some compensation.
}

The decision to rent out to a relative, rather than any other household or institution, is likely to be a function of the household's family connections and the level of trust in other community members. More specifically, landlords that were born in the village and have a lower level of trust in their neighbours are more likely to lease land to their relatives. Since these variables should not affect households' decision/capability to receive a compensation for the plots rented out (at least once other household and plot characteristic are controlled for), they plausibly satisfy the exclusion restrictions. Therefore, the estimation of the selection model is achieved by adding to the first stage a binary variable taking value 1 if the head was born in the commune and a dummy indicating whether the head would rather receive 3 acres of land to farm along with a neighbour he/she is not related to (signalling good level of trust) or 1 acre to farm alone.

Another important challenge for the identification is that plot certification is not exogenous. If we do not capture some unobservable characteristics that might affect both the decision to obtain a LUC for a given plot and the likelihood to receive some rent when the land is leased out, our estimates may be biased. To address this concern we control for community level time-invariant factors through commune fixed effects, as well as several household and plot level characteristics. Nonetheless, there is still the possibility that we are failing to account for some relevant yet unobservable dimensions. Ideally, we would like these unobservable factors to not be correlated with the probability of receiving compensation when leasing out land to a relative, however it is not possible for us to rule out this possibility. Hence, our estimates may suffer from omitted variable bias.

\section{Results and discussion}

In this section we present and comment on the empirical results based on the specifications described above. Furthermore, we present some insightful region-specific estimates. Because of historical reasons, the evolution of social institutions and attitudes towards private property rights differ significantly between the North and the South of Viet Nam. Hence, an aggregate analysis might be overlooking relevant heterogeneity in the impact of land certification. We also discuss the implications of our findings for agricultural production and household income, and the policy implications of our findings.

\subsection{Land use certificates and rental compensation}

Table 3 displays a number of different estimates of the simple linear probability model. Whenever the interaction term is not added (columns 1 and 2), the estimate of $\beta_{1}$ is negative but not statistically significant, suggesting that female-headed households are not more likely to rent land out for free to their relatives. However, the coefficient turns positive and significant when the interaction term is included in column 3 . This indicates that when female landlords lease untitled plots to their relatives, they are less likely to receive any type of compensation.

Our results suggest land certification makes up for female-headed household's weaker tenure security. We can infer this because $\beta_{3}$ is always negative and statistically significant, and the magnitude of its point estimate is never statistically different from $\beta_{1}{ }^{19}$ Moreover, LUCs are shown to have no impact on the probability that male-headed households rent out their land for free to their relatives, as $\beta_{2}$ is never statistically significant. This suggests that men's decision to rent plots for free to their relatives is not related to the possession of a LUC. Adding household (column 4) and plot (column 5) characteristics does not affect these conclusions and if anything improves the significance levels.

\footnotetext{
${ }^{19}$ Although the point estimates for $\beta_{3}$ are always larger than $\beta_{1}$, the difference (in magnitude) between the two coefficients is never statistically significant as indicated by the results of the formal tests presented in Table 3 , that always fail to reject the null hypothesis $\beta_{1}=-\beta_{3}$.
} 
Table 3

Plot level linear probability model (plots rented out to relatives).

Source: Authors' computation based on VAHRS data.

Dep variable: Plot rented out for free conditional on being rented out to relatives

\begin{tabular}{|c|c|c|c|c|c|c|c|c|}
\hline & (1) & (2) & (3) & (4) & (5) & (6) & (7) & (8) \\
\hline Female & $\begin{array}{l}-0.024 \\
(0.04)\end{array}$ & $\begin{array}{l}-0.024 \\
(0.04)\end{array}$ & $\begin{array}{l}0.130 * \\
(0.07)\end{array}$ & $\begin{array}{l}0.167^{* * *} \\
(0.08)\end{array}$ & $\begin{array}{l}0.158^{* *} \\
(0.08)\end{array}$ & $\begin{array}{l}0.164^{*} \\
(0.09)\end{array}$ & $\begin{array}{l}0.182^{* *} \\
(0.08)\end{array}$ & $\begin{array}{l}0.191^{*} \\
(0.09)\end{array}$ \\
\hline LUC & & $\begin{array}{l}0.000 \\
(0.04)\end{array}$ & $\begin{array}{l}0.044 \\
(0.04)\end{array}$ & $\begin{array}{l}0.049 \\
(0.04)\end{array}$ & $\begin{array}{l}0.042 \\
(0.04)\end{array}$ & $\begin{array}{l}0.024 \\
(0.04)\end{array}$ & $\begin{array}{l}0.037 \\
(0.04)\end{array}$ & $\begin{array}{l}0.027 \\
(0.04)\end{array}$ \\
\hline LUC*Female & & & $\begin{array}{l}-0.194^{* *} \\
(0.08)\end{array}$ & $\begin{array}{l}-0.199^{* * *} \\
(0.08)\end{array}$ & $\begin{array}{l}-0.193^{* *} \\
(0.08)\end{array}$ & $\begin{array}{l}-0.206^{* *} \\
(0.09)\end{array}$ & $\begin{array}{l}-0.237^{* * *} \\
(0.09)\end{array}$ & $\begin{array}{l}-0.257^{*} \\
(0.10)\end{array}$ \\
\hline Year FE & Yes & Yes & Yes & Yes & Yes & Yes & Yes & Yes \\
\hline Commune FE & Yes & Yes & Yes & Yes & Yes & Yes & Yes & Yes \\
\hline $\mathrm{HH}$ controls & No & No & No & Yes & Yes & Yes & Yes & Yes \\
\hline Plot controls & No & No & No & No & Yes & Yes & Yes & Yes \\
\hline p-value $\beta_{1}=-\beta_{3}$ & - & - & 0.15 & 0.67 & 0.69 & 0.59 & 0.47 & 0.45 \\
\hline Mean y & 0.64 & 0.64 & 0.64 & 0.64 & 0.64 & 0.65 & 0.63 & 0.65 \\
\hline$N$ & 2930 & 2930 & 2930 & 2930 & 2930 & 2596 & 2677 & 2359 \\
\hline Clusters & 556 & 556 & 556 & 556 & 556 & 484 & 507 & 438 \\
\hline adj. $R^{2}$ & 0.381 & 0.381 & 0.381 & 0.385 & 0.387 & 0.370 & 0.391 & 0.407 \\
\hline
\end{tabular}

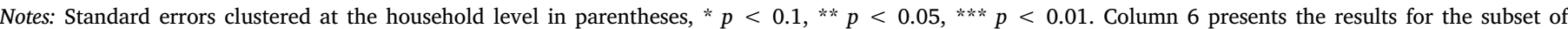

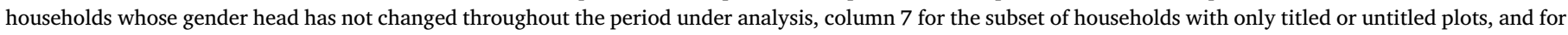
column 8 the intersection between these two sets.

In the remaining columns, we re-estimate the same regression on some sub-samples of the population as a robustness check. In order to rule out the possibility that the results are driven by shocks leading to a change in the household head, in column 6 we restrict the sample to those households whose gender of the head has remained the same throughout the 5 waves. In column 7, we only include households who have all or none of their plots titled (around 90 percent of the observations), to address some concerns related to unobservable heterogeneity in land quality at the plot level. Finally, in column 8 we include only households whose gender of the head never change and that have either all or none of their land titled. The results are consistent across all the specifications and corroborate our initial findings.

In terms of economic significance, the estimates of the gap are definitely relevant. In particular, since the unconditional probability of a plot being rented out for free when the tenant is a relative is 0.64 and the point estimates of $\beta_{1}$ range between 0.13 and 0.19 , female-headed households are 25 per cent less likely to receive any monetary or inkind compensation when renting land to their relatives. This significant unbalance is entirely offset by the possession of land use certificates.

There are substantial regional differences that may have shaped the way land markets evolved in Viet Nam and their current functioning. While the Northern regions of Viet Nam had a collectivized agricultural production system since the 1950 s, in the South this system was not introduced until the late 1970s. Even after the country's reunification, many farmers in the South resisted collectivization: as late as 1986-when collectivization was starting to be reversed in all the country-less than 10 per cent of the rural households in the Mekong Delta region had been organized into cooperatives (Pingali and Xuan, 1992). For this reason, we believe the role of LUCs in land rental market behavior may be considerably different between North and South Viet Nam.

The figures shown in Table 4 provide an overall description of the differences between North and South Viet Nam in terms of land rentals. In the North, landlords are more likely to rent out their plots for free and/or to relatives. This tendency is more pronounced among plots that are rented out in our sample, but it is statistically significant also among the ones that are leased in.

As outlined in the Section 5, one potential concern related to the simple linear probability model presented in Table 4 is that it fails to take into account for potential sample selection. Indeed, the analysis involves only the plots that are rented out to relatives, which might
Table 4

Type of landlords, tenants and rental agreement by region. Source: Authors' computation based on VAHRS data.

\begin{tabular}{llll}
\hline & North & South & p-value difference \\
\hline Plots rented out to relatives & 0.67 & 0.60 & 0.00 \\
Plots rented out for free & 0.57 & 0.33 & 0.00 \\
N & 2100 & 1022 & - \\
Plots rented in from relatives & 0.50 & 0.42 & 0.00 \\
Plots rented in for free & 0.38 & 0.26 & 0.00 \\
N & 3454 & 924 & - \\
\hline
\end{tabular}

differ from the other plots in the rental market along some unobserved dimensions. ${ }^{20}$ If these characteristics affect also the likelihood of receiving rent, our estimates would be biased. For this reason, we also present the results obtained applying the two-step procedure proposed by Ahn and Powell (1993) to correct for the potential sample selection bias.

Table 5 shows the estimates for both the simple linear probability model (columns 1 to 3 ) and the model with adjustments for sample selection (columns from 4 to 6 ). ${ }^{21}$ In order to check whether there is any appreciable regional difference, the regressions are estimated for the subsample of plots in the North (columns 2 and 5) and in the South (columns 3 and 6) only. ${ }^{22}$

As far as the sample selection models are concerned, it is clear that they deliver results which are entirely in line with the simple linear models. In fact, magnitude, signs and significance of the coefficients of interest are virtually indistinguishable. As for the regional

\footnotetext{
${ }^{20}$ Similarly, we cannot rule out the possibility that households leasing land out for free differ from the others in ways that are not captured by the household level controls included.

${ }^{21}$ Columns 4 to 6 present the coefficients from the second step. Since it is a linear probability model, they can be interpreted as marginal effects and be directly compared to the estimates in columns 1 to 3 .

${ }^{22}$ Provinces in the Northern Lowlands (Ha Tay, Phu To and Nghe An) and Northern Highlands (Lao Cai, Lai Chau and Dien Bien) areas are included in the Northern region, while the Southern region contains provinces located in the Southern Lowlands (Quang Nam, Khan Hoa and Long an) and in the Southern Highlands (Dak Lak, Dak Nong and Lam Dong).
} 
Table 5

Sample selection model estimates, by region.

Source: Authors' computation based on VAHRS data.

\begin{tabular}{|c|c|c|c|c|c|c|}
\hline & \multicolumn{3}{|c|}{ No sample selection correction } & \multicolumn{3}{|c|}{ Sample selection correction } \\
\hline & $\begin{array}{l}\text { All } \\
(1)\end{array}$ & $\begin{array}{l}\text { North } \\
\text { (2) }\end{array}$ & $\begin{array}{l}\text { South } \\
\text { (3) }\end{array}$ & $\begin{array}{l}\text { All } \\
(4)\end{array}$ & $\begin{array}{l}\text { North } \\
\text { (5) }\end{array}$ & $\begin{array}{l}\text { South } \\
\text { (6) }\end{array}$ \\
\hline Female & $\begin{array}{l}0.158^{\text {*** }} \\
(0.08)\end{array}$ & $\begin{array}{l}0.191^{k * k} \\
(0.08)\end{array}$ & $\begin{array}{l}-0.039 \\
(0.22)\end{array}$ & $\begin{array}{l}0.165^{\text {*** }} \\
(0.08)\end{array}$ & $\begin{array}{l}0.171^{\text {k*k }} \\
(0.08)\end{array}$ & $\begin{array}{l}-0.009 \\
(0.22)\end{array}$ \\
\hline LUC & $\begin{array}{l}0.042 \\
(0.04)\end{array}$ & $\begin{array}{l}0.067 \\
(0.04)\end{array}$ & $\begin{array}{l}-0.110 \\
(0.13)\end{array}$ & $\begin{array}{l}0.052 \\
(0.04)\end{array}$ & $\begin{array}{l}0.067 \\
(0.04)\end{array}$ & $\begin{array}{l}-0.090 \\
(0.12)\end{array}$ \\
\hline LUC*Female & $\begin{array}{l}-0.193^{\text {*k* }} \\
(0.08)\end{array}$ & $\begin{array}{l}-0.240^{\text {**** }} \\
(0.09)\end{array}$ & $\begin{array}{l}0.098 \\
(0.21)\end{array}$ & $\begin{array}{l}-0.208^{\text {k* }} \\
(0.08)\end{array}$ & $\begin{array}{l}-0.206^{\text {*k }} \\
(0.09)\end{array}$ & $\begin{array}{l}0.019 \\
(0.21)\end{array}$ \\
\hline Year FE & Yes & Yes & Yes & Yes & Yes & Yes \\
\hline Commune FE & Yes & Yes & Yes & Yes & Yes & Yes \\
\hline $\mathrm{HH}$ controls & Yes & Yes & Yes & Yes & Yes & Yes \\
\hline Plot controls & Yes & Yes & Yes & Yes & Yes & Yes \\
\hline $\mathrm{p}$-value $\beta_{1}=-\beta_{3}$ & 0.69 & 0.40 & 0.40 & 0.39 & 0.58 & 0.88 \\
\hline Mean y & 0.64 & 0.70 & 0.41 & 0.64 & 0.70 & 0.41 \\
\hline Clusters & 556 & 379 & 177 & 556 & 379 & 177 \\
\hline$N$ & 2,930 & 2,370 & 560 & 2,930 & 2,370 & 560 \\
\hline adj. $R^{2}$ & 0.387 & 0.343 & 0.424 & 0.385 & 0.346 & 0.433 \\
\hline
\end{tabular}

Notes: Standard errors clustered at the household level in parentheses, ${ }^{*} p<0.1, * * p<0.05, * * * p<0.01$.

decomposition, the findings seem to indicate that the aggregate results were mostly driven by households located in the Northern region (which represents more than three quarters of the whole sample). In fact, none of the coefficients under analysis is statistically significant for the Southern region subsample. This indicates that in the South, femaleheaded households are as likely as the others to receive rent for the plots rented out and that the possession of a LUC does not increase the likelihood to receive any compensation.

The results are crucially different for the Northern region. Namely, female-headed households without LUCs are 27 percent more likely to rent out plots for free (24 percent according to the selection model). This gap is entirely eliminated by the possession of LUCs for the plots, which has a significant impact only on female-headed households. These findings indicate that land use certificates improve the bargaining power of female-headed households, who otherwise seem to be disadvantage by the existing norms governing land practices. In particular, once they have a formal certificate, they become as likely as men to receive some compensation for the plots rented out to relatives.

\subsection{Productivity losses}

We expect market-based transactions (those with an agreed compensation) to improve efficiency more than non-market land transfers. This is because they are the manifestation of gains from trade that occur when land is transferred from less to more productive producers. Empirical evidence from Ethiopia shows that informal land transactions, un-like market-based rentals, do not lead to an improvement in agricultural productivity and factor allocation (Chen et al., 2017).

Unfortunately, a direct comparison of the productivity of tenants and owners cannot be performed as we do not have data about the production undertaken on plots that have been rented out by the households in the sample. However, we can still obtain some insights by comparing the yields of farmers who rent land in. ${ }^{23}$ Specifically, we want to test whether households that rent in plots with an agreed

\footnotetext{
${ }^{23}$ Even though these households are not exactly the ones we are observing when analysing the effects of LUCs on landlord's tenant choice and rental agreement, we think that they will capture the overall effects of land rental market behaviour on agricultural production since it refers to the demand side of the rental market.
}

compensation (monetary or in-kind) are actually more productive than those that rent in land for free. We focus on rice production to operate with a consistent measure of productivity across time and regions. This still gives us a representative picture of agricultural activity as rice is by far the most important crop in Viet Nam.

Some suggestive evidence in this sense can be derived simply by estimating the rice yields of all plots rented in and testing whether they differ significantly depending on the type of contract (free rental or not). The results of this exercise are displayed in Table 6. The first column shows the average for the entire sample, the second column shows the average of plots that were rented in for free, and the third column gives us the average yields of plots that were rented in with some agreed compensation. The first interesting fact we can observe is that rice productivity has increased by more than 7 percent between 2008 and 2016. Moreover, rice productivity on plots rented in (both market and non-market) is higher than that of the entire sample in every period. However, in line with our hypothesis, we also see that, for each year, the yields were significantly higher in plots rented in for a fixed compensation than for those rented in for free (p-values are indicated in the fourth column). The difference between market and nonmarket transfers is also economically significant, ranging from 3 percent in 2012 to 7.5 percent in 2016 .

However, it is possible that these findings are driven by other factors than systematic differences in productivity between tenants renting in for free and those who pay for the land. In particular, they might reflect differences in plot specific characteristics (e.g. land quality and irrigation facilities) or other variables such as input intensity in rice production. In order to address these concerns, we move the analysis to the household level, and estimate the following regression:

$$
\begin{aligned}
\log \left(\text { yield }_{i t}=\right. & \beta_{1} \text { Renting in } \\
& +X_{i t}^{\prime} \gamma+\beta_{2} \text { Renting } \tau_{t}+\varsigma_{z}+\varepsilon_{i t} * \text { No rent paid }
\end{aligned}
$$

The dependent variable is the logarithm of the rice yield of farmer $i$ in time $t$ and is computed aggregating the production (and land input) across all the plots cultivated by the household, including both owned and rent-in plots. "Renting in" is a dummy variable taking value one when the household $i$ is renting at least one plot in period $t$ (regardless of whether they are paying for it or not), while "No rent paid" is a dummy variable that takes value 1 when households do not pay rent for 
Table 6

Average rice yields ( $\mathrm{t} / \mathrm{ha}$ ) of plots rented in by year and type of contract. Source: Authors' computation based on VAHRS data.

\begin{tabular}{lllll}
\hline & All sample & $\begin{array}{l}\text { Renting in for } \\
\text { free }\end{array}$ & $\begin{array}{l}\text { Renting in for } \\
\text { compensation }\end{array}$ & $\begin{array}{l}\text { p-value } \\
\text { difference }\end{array}$ \\
\hline 2008 & 4.54 & 4.69 & 4.93 & 0.04 \\
2010 & 4.56 & 4.73 & 4.94 & 0.08 \\
2012 & 4.72 & 4.86 & 5.02 & 0.09 \\
2014 & 4.85 & 4.79 & 5.09 & 0.02 \\
2016 & 4.87 & 4.92 & 5.29 & 0.00 \\
Overall & 4.71 & 4.81 & $\mathbf{5 . 0 3}$ & $\mathbf{0 . 0 0}$
\end{tabular}

any of the plots rented in. ${ }^{24} X$ is a vector of controls which captures input intensity and land quality, $\tau$ is a set of year fixed effects, $\varsigma$ represents the province or commune fixed effects, and $\varepsilon$ is the error term. ${ }^{25}$

The coefficients of interest are $\beta_{1}$ and $\beta_{2}$ representing respectively the productivity gap between households who rent land in and those who do not, and the difference between the yield obtained by tenants who pay for the plots they lease in and those who do not. ${ }^{26}$ As shown in Table $7, \beta_{2}$ is negative and significant across all specifications, indicating that farmers who rent in land for free obtain lower yields than those who pay for it, even after controlling for differences in land quality and input intensity. Likewise, $\beta_{1}$ is always positive and statistically significant which suggests households that rent land in are more productive than those that do not. However, this positive impact of land rentals on productivity is likely just driven by market transactions because $\beta_{1}+\beta_{2}$ is never statistically different from zero, suggesting that farmers renting in land for free are not more productive than those that do not rent in any land.

These estimates are also economically significant. Depending on the specifications, farmers who rent in land for a price tend to reach from 3 to 6 percent higher yields than those who rent in for free. This represents about half the impact of possessing an irrigation system according to our estimates. As possessing a land use certificate increases the likelihood of female-headed households to engage in market-based transactions, they are also expected to increase agricultural productivity through a better allocation of resources.

\subsection{Income losses}

By renting out land for free, households are potentially giving up a relevant source of income. In order to quantify the magnitude of this phenomenon, we estimate a time-province average rental rate using the

\footnotetext{
${ }^{24} 95 \%$ of households renting land in either rent all the plots for free or pay for all of them. We remove the households that have both plots rented in for free and for compensation to maintain a consistent comparison among household productivity.

${ }^{25}$ Land quality measures are fertility, slope and irrigation. As they are originally ordered categorical variables defined at the plot level, they are aggregated at the holding level with a two steps procedure. First of all, a weighted average is computed using the plots' area as weights. Then, the variables obtained are rounded to the closest integer to be assigned to each category. Although household head characteristics are also likely to affect productivity, we do not control for them. The reason is that we want to understand the production implications of land rental markets, particularly the differences between market and non-market transactions. Hence, if a farmer obtains land through the market because she is better educated or younger (observable features that are positively related to ability), this does not concern us as it is still efficiency enhancing that younger and more educated farmers obtain more agricultural factors.

${ }^{26}$ Note that by construction the dummy variable "No rent paid" can only take value 1 when "Renting in" is equal to 1 as well, therefore the same results would have been obtained by entering the two dummies separately as opposed to the interaction term.
}

Table 7

OLS results on the effect of market and non-market rentals on rice productivity. Source: Author's calculation based on VARHS data.

\begin{tabular}{|c|c|c|c|c|}
\hline & (1) & (2) & (3) & (4) \\
\hline Rent land in & $\begin{array}{l}0.044^{* * * * *} \\
(0.01)\end{array}$ & $\begin{array}{l}0.061^{* * * * *} \\
(0.01)\end{array}$ & $\begin{array}{l}0.050^{\text {***i* }} \\
(0.01)\end{array}$ & $\begin{array}{l}0.031^{* * * *} \\
(0.01)\end{array}$ \\
\hline $\begin{array}{l}\text { Rent land in * Rent } \\
\text { land for free }\end{array}$ & $-0.050^{* \text { *⿻一丿火 }}$ & $-0.062^{* * * * *}$ & $-0.047^{* k \times * k}$ & $-0.024 *$ \\
\hline Land farmed (log) & $(0.02)$ & $\begin{array}{l}(0.02) \\
-0.087^{\text {***** }} \\
(0.01)\end{array}$ & $\begin{array}{l}(0.01) \\
-0.092^{\text {wktkt }} \\
(0.01)\end{array}$ & $\begin{array}{l}(0.01) \\
-0.114^{* * * x} \\
(0.01)\end{array}$ \\
\hline Labour days (log) & & $\begin{array}{l}0.051^{* * * *} \\
(0.01)\end{array}$ & $\begin{array}{l}0.051^{\text {***k* }} \\
(0.01)\end{array}$ & $\begin{array}{l}0.065^{* * * k} \\
(0.01)\end{array}$ \\
\hline Irrigation $(1=$ yes $)$ & & & $\begin{array}{l}0.122^{* * * * *} \\
(0.01)\end{array}$ & $\begin{array}{l}0.062^{* * * *} \\
(0.01)\end{array}$ \\
\hline \multicolumn{5}{|l|}{ Fertility (base $=$ low) } \\
\hline Medium & & & $\begin{array}{l}0.109^{\text {*k*kth}} \\
(0.01)\end{array}$ & $\begin{array}{l}0.103^{\text {*.*kt }} \\
(0.01)\end{array}$ \\
\hline High & & & $\begin{array}{l}0.132^{\text {w*k* }} \\
(0.02)\end{array}$ & $\begin{array}{l}0.109^{* * * *} \\
(0.02)\end{array}$ \\
\hline \multicolumn{5}{|l|}{ Slope (base $=$ flat) } \\
\hline Slight Slope & & & $\begin{array}{l}-0.103^{\text {*k*** }} \\
(0.01)\end{array}$ & $\begin{array}{l}-0.039^{* * * x} \\
(0.01)\end{array}$ \\
\hline Steep & & & $\begin{array}{l}-0.177^{\text {totkt }} \\
(0.02)\end{array}$ & $\begin{array}{l}-0.064^{*+x^{*}} \\
(0.02)\end{array}$ \\
\hline Very steep & & & $\begin{array}{l}-0.382^{\text {s.knk }} \\
(0.11)\end{array}$ & $\begin{array}{l}-0.222^{* * *} \\
(0.09)\end{array}$ \\
\hline Year FE & Yes & Yes & Yes & Yes \\
\hline Province FE & Yes & Yes & Yes & No \\
\hline Commune FE & No & No & No & Yes \\
\hline $\mathrm{p}$-value $\beta_{1}=\beta_{2}$ & 0.76 & 0.87 & 0.70 & 0.41 \\
\hline$N$ & 8,197 & 8,197 & 8,197 & 8,197 \\
\hline adj. $R^{2}$ & 0.149 & 0.171 & 0.229 & 0.367 \\
\hline
\end{tabular}

Notes: Robust standard errors in parentheses, ${ }^{*} p<0.1, * * p<0.05$, *** $p<0.01$.

value households report to pay (in the case of land rented in) or receive (in the case of land rented out). We then use this rental rate to compute the income loss for households that rent out land for free. Specifically, we estimate the rental rate by running an OLS regression where the dependent variable is the household rent per square meter paid/received for plots rented in/out controlling for province and time fixedeffects, as well as a number of plot characteristics. ${ }^{27}$ According to our estimates, households who rent out land for free are renouncing, on average, to receive a rent that represents around 5 percent of their total income.

As we mention before, the subsample of landlords is quite heterogeneous. On one side, some farmers rent out land because they are leaving agriculture for more profitable activities (rich landlords). On the other, farmers with limited non-land agricultural factors are no longer able to cultivate all of their landholdings so they lease out their property (poor landlords). Therefore, we provide a more disaggregated analysis based on income to better understand the implications of nonmarket rentals for income dynamics.

In Fig. 1, we present the mean and standard deviation of the potential income lost faced by each landlord that leases land for free, by income quintiles. ${ }^{28}$ From the corresponding results, it is clear that the impact on poorer households is quite remarkable. For households in the

\footnotetext{
${ }^{27}$ Namely, we control for plot size, self-reported fertility, slope, irrigation, crop-choice restrictions and whether is devoted to annual or perennial crops.

${ }^{28}$ The income quintiles are computed using the entire household sample. The richest quintile has the higher proportion of households renting out land for free. Indeed, 30 percent of landlords leasing out for free belong to the highest quintile.
} 


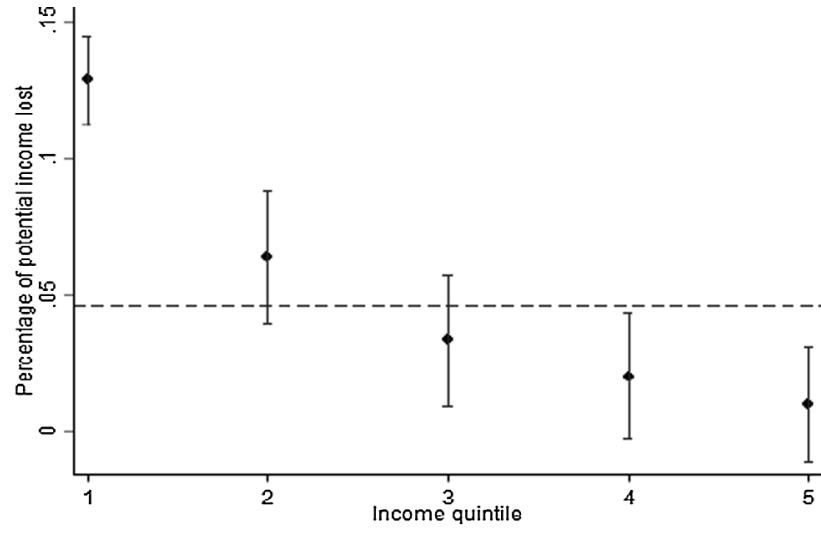

Fig. 1. Average and standard deviations of potential income losses by income quintiles. Note: The horizontal dotted line represents the sample average, the points are the means for each quintile and the vertical lines the standard deviation of the quintile specific averages. Source: Authors' calculation based on VAHRS data.

lowest income quintile, the income loss represents on average almost 12 percent of their annual income. This is a particularly relevant for female-headed households as they are over represented in the lowest quintiles. In the case of landlords leasing land out for free, 54 percent of the female-headed households belong to the two bottom quintiles (35 percent to the bottom one) as opposed to only 27 percent for men (13 percent to the bottom one).

\subsection{Policy implications}

The high prevalence of informal transactions in land rentals markets raises concerns because of two factors. First, it may reduce overall agricultural productivity because the farmers who obtain the land are not the most capable. Second, these transactions can partly be the reflection of a weak enforcement of property rights, leading those with tenure insecurity to lease their land in less favourable terms. In support of the latter hypothesys, we show that women have a higher probability of leasing their land for free to their relatives unless they possess a LUC for the plot. Such informal transactions have detrimental effects on both agricultural production and landlords' income. In particular, we find that tenants obtaining land for free deliver systematically lower yields than those who acquire it through market transactions, and that poor landlords are giving up a significant share of their income by not obtaining any compensation from their tenants.

Interestingly, our findings on women's rental market parcipation are mostly driven by the dynamics of rental markets in the North of Viet Nam; a region where land institutions are historically different and the process of transition in a agriculture to a market-based activity has not fully materialised. This result highlights the importance of paying close attention to the certification of land for groups that have been traditionally marginalized in terms of access to resources.

\section{Conclusions}

In the period under analysis, Viet Nam has witnessed a remarkable growth in land rental market activity, with a nearly 50 percent increase in the share of agricultural plots that were rented in or out by rural households. Interestingly, a considerable number of these temporary land transfers occurred among relatives and did not contemplate any type of compensation to the landowner. Understanding the implications of these non-market transactions is very important, particularly in Viet Nam where, despite rapid growth in productivity and land transfers, agricultural factor misallocation has increased in the last 10 years (Ayerst et al., 2018).

In this paper we provide evidence that some of these informal transactions are the result of differences in power between female and male-headed households. According to our results, female-headed households are less likely to receive any rent payment when they lease out their plots to relatives, unless they have a certificate for the plot. This suggests that they might have weaker rights over the land, but legal documents strengthen their claims over their assets and increase their bargaining power in the negotiation of the rental terms. Additionally, we quantify the impact of these transactions for agricultural production and household income.

There are significant differences between the Northern and Southern provinces in terms of their social institutions and attitudes towards market-oriented policies, particularly in agrarian issues. We show that our results are being driven mostly by the dynamics of the land rental market in the North. In this region, where land transactions among relatives are common both for male and female landlords, female-headed households are more likely to receive compensation when they have a LUC for the plots they lease out. In the South, the possession of a land title does not affect women's probability of receiving a payment when leasing out to relatives.

Our results suggest that clear and enforceable property rights have a positive impact on female-headed households' ability to obtain a more convenient agreement when renting land to members of their family. By improving the bargaining power of groups with weaker ex-ante property rights, land use certificates might not just guarantee a fair compensation to vulnerable households but also contribute to allocate land to farmers willing to pay for it (and arguably more productive) rather than to individuals obtaining it by virtue of their relative strength in the extended family.

\section{Acknowledgements}

We are indebted to Carol Newman for her thorough guidance and support in developing this project. We are grateful to all the participants at the Viet Nam Access to Rural Household Survey workshop in Helsinki for their useful comments and to UNU-WIDER for the support. We also want to thank two anonymous referees for their helpful comments. All remaining errors are our own.

\section{Appendix A. Unilateral transfers from relatives}

As pointed out in the previous sections, one of the main concerns related to the increasing share of informal transactions in the land rental markets, beside the arguments related to the potential resulting inefficiencies, is that landlords might fail to receive an adequate compensation for their land. The issue is particularly crucial as a large fraction of the landlords in our sample is constituted by poor female-headed households.

However, there is the possibility that households renting their agricultural plots for free might receive some sort of indirect compensation in the form of unilateral cash or in-kind transfers not directly included in the contract. ${ }^{29}$ We are not directly able to rule out this possibility as we do not have any further information on the contract terms and on the identity of the relatives acting as tenants, but we can study whether renting out plots to relatives for free is correlated with an increase in the probability of receiving unilateral transfers from relatives (not necessarily the same) or in their total amount.

\footnotetext{
${ }^{29}$ From the questionnaire, we only know whether any form of direct compensation (in cash or kind) was contemplated by the rental agreement.
} 
Table A1

Transfers from relatives outside households. Dependent variable: household receives transfers from relatives $($ Yes $=1$ ).

Source: Authors' computation based on VAHRS data.

\begin{tabular}{|c|c|c|c|c|}
\hline & (1) & (2) & (3) & (4) \\
\hline Renting out for free (yes $=1$ ) & $\begin{array}{l}-0.015 \\
(0.02)\end{array}$ & $\begin{array}{l}-0.006 \\
(0.03)\end{array}$ & - & - \\
\hline Area rented for free $(\log )$ & - & - & $\begin{array}{l}-0.002 \\
(0.01)\end{array}$ & $\begin{array}{l}-0.011 \\
(0.02)\end{array}$ \\
\hline$\%$ Person days lost (shocks) & $\begin{array}{l}0.405^{* * *} \\
(0.06)\end{array}$ & $\begin{array}{l}0.343^{* * *} \\
(0.09)\end{array}$ & $\begin{array}{l}0.407^{* * *} \\
(0.06)\end{array}$ & $\begin{array}{l}0.346^{* * *} \\
(0.09)\end{array}$ \\
\hline Interaction & $\begin{array}{l}0.004 \\
(0.12)\end{array}$ & $\begin{array}{l}-0.010 \\
(0.17)\end{array}$ & $\begin{array}{l}-0.002 \\
(0.02)\end{array}$ & $\begin{array}{l}-0.017 \\
(0.02)\end{array}$ \\
\hline Year FE & Yes & Yes & Yes & Yes \\
\hline Commune FE & Yes & Yes & Yes & Yes \\
\hline Household covariates & Yes & No & Yes & No \\
\hline Household FE & No & Yes & No & Yes \\
\hline $\mathrm{N}$ & 10,655 & 10,655 & 10,655 & 10,655 \\
\hline Adj- $R^{2}$ & 0.122 & 0.102 & 0.122 & 0.102 \\
\hline
\end{tabular}

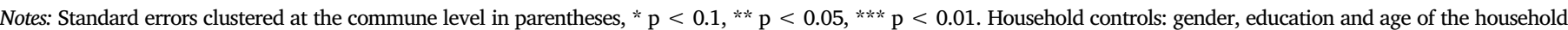

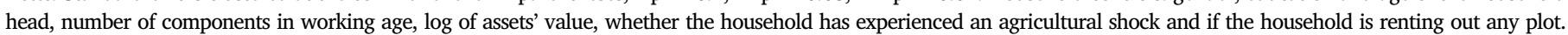

Table A2

Transfers from relatives outside the household. Dependent variables: Value of transfers received from relatives (log).

Source: Authors' computation based on VAHRS data.

\begin{tabular}{|c|c|c|c|c|}
\hline & (1) & (2) & (3) & (4) \\
\hline Renting out for free & $\begin{array}{l}-0.037 \\
(0.22)\end{array}$ & $\begin{array}{l}0.081 \\
(0.28)\end{array}$ & - & - \\
\hline Area rented for free (log) & - & - & $\begin{array}{l}-0.000 \\
(0.04)\end{array}$ & $\begin{array}{l}0.011 \\
(0.04)\end{array}$ \\
\hline$\%$ Person days lost (shocks) & $\begin{array}{l}3.742 * * * \\
(0.58)\end{array}$ & $\begin{array}{l}3.515^{* * *} \\
(0.83)\end{array}$ & $\begin{array}{l}3.773^{* * * *} \\
(0.58)\end{array}$ & $\begin{array}{l}3.540 * * * \\
(0.84)\end{array}$ \\
\hline Interaction & $\begin{array}{l}0.877 \\
(1.23)\end{array}$ & $\begin{array}{l}0.040 \\
(1.58)\end{array}$ & $\begin{array}{l}-0.092 \\
(0.17)\end{array}$ & $\begin{array}{l}-0.024 \\
(0.22)\end{array}$ \\
\hline Year FE & Yes & Yes & Yes & Yes \\
\hline Commune FE & Yes & Yes & Yes & Yes \\
\hline Household covariates & Yes & No & Yes & No \\
\hline Household FE & No & Yes & No & Yes \\
\hline $\mathrm{N}$ & 10,655 & 10,655 & 10,655 & 10,655 \\
\hline Adj- $R^{2}$ & 0.149 & 0.151 & 0.149 & 0.151 \\
\hline
\end{tabular}

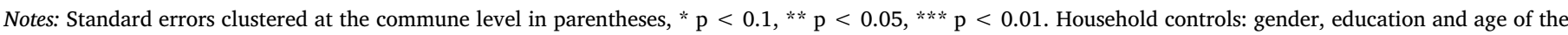

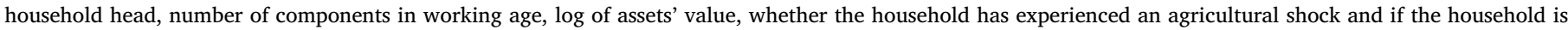
renting out any plot.

In order to check whether it is the case, the following household regression is estimated:

Transfers $_{h t}=\beta_{1}$ landforfree $_{h t}+\beta_{2}$ shock $_{h t}+\beta_{3}$ landforfree $_{h t} *$ shock $_{h t}+\mathrm{X}_{\mathrm{ht}}^{\prime} \gamma+\varepsilon_{h t}$

and the resulting estimates are displayed in Table A1 and Table A2. ${ }^{30}$

In particular, the dependent variable is either a dummy taking value 1 when the household receives unitary monetary transfers from its relatives (Table A1) or the logaritm of the value of these transfers (Table A2). We are prevalently interested in assessing whether having some plots of land rented out to relatives for free increases the probability and/or the amount of the transfers received, captured by the coefficient $\beta_{1}$. In the first two columns, the main explanatory variable is a dummy that indicating whether the household is renting at least one plot for free, while in columns 3 and 4 the log of the area of land rented out for free is considered.

Another possibility that needs to be taken into account is that leasing land for free to relatives might be conceived as a way to ensure a safety net in case of unexpected negative shocks (Promsopha, 2015). If that was the case, this behaviour would not necessarily give rise to an increase in the unilateral transfers, but rather to an increased support from relatives in case of negative shocks. The occurrence as well as the gravity of household level shocks are captured by the percentage of person days lost due to adverse circumstances in the previous year, computed as the fraction of days working age individuals were not able to work due to illness or injuries. This variable is also interacted with either the dummy indicating whether land is rented out for free (columns 1 and 2) or to the acreage of plots given out for no compensation in order to assess whether these transfersactually lead to a more substantial support in case of unforeseen detrimental shocks.

According to our estimates, neither renting at least one plot to relatives for free nor the total area of land rented out to relatives without receiving any direct compensation has any impact on the probability of receiving some transfers (Table A1) or on the amount of the transfers received (Table A2). Moreover, although households suffering shocks are more likely to receive transfers, we find no evidence of a higher amounts being transferred to those who have some land leased out for free to relatives. ${ }^{31}$ These findings seem to exclude these free rental contracts have any indirect benefit to the landlords.

\footnotetext{
${ }^{30}$ Note that the dependent variable refers only unilateral transfers. Therefore, the cash inflows for land rented out or other transactions are not included.

${ }^{31}$ The regressions presented include household level covariates (columns 1 and 3) or fixed effects (columns 2 and 4 ), but the results are robust to a wide range of specifications.
} 


\section{References}

Adamopoulos, T., Brandt, L., Leight, J., Restuccia, D., 2017. Misallocation, selection and productivity: A quantitative analysis with panel data from China (No. w23039). National Bureau of Economic Research.

Agarwal, B., 1995. A field of one's own: Gender and land rights in South Asia, vol. 58 Cambridge University Press.

Ahn, H., Powell, J.L., 1993. Semiparametric estimation of censored selection models with a nonparametric selection mechanism. J. Econometr. 58 (1-2), 3-29.

Akram-Lodhi, A.H., 2005. Vietnam's agriculture: processes of rich peasant accumulation and mechanisms of social differentiation. J. Agrar. Change 5 (1), 73-116.

Ayerst, S., Brandt, L., Restuccia, D., 2018. Market Constraints, Misallocation, and Productivity in Vietnam Agriculture. Unpublished Manuscript. University of Toronto.

Bellemare, M.F., 2012. Insecure land rights and share tenancy: evidence from Madagascar. Land Econ. 88 (1), 155-180.

Banerjee, A.V., Gertler, P.J., Ghatak, M., 2002. Empowerment and efficiency: tenancy reform in West Bengal. J. Polit. Econ. 110 (2), 239-280.

Besley, T., Ghatak, M., 2010. Property rights and economic development' Handbook of Development Economics, vol. 5, 4525-4595.

Chari, A.V., Liu, E.M., Wang, S.Y., Wang, Y., 2017. Property Rights, Land Misallocation and Agricultural Efficiency in China. National Bureau of Economic Research No, Cambridge, MA, pp. w24099.

Chen, C., Restuccia, D., Santaeulàlia-Llopis, R., 2017. Land Markets, Resource Allocation, and Agricultural Productivity. Unpublished Manuscript. University of Toronto.

Deininger, K., Jin, S., 2005. The potential of land rental markets in the process of economic development: Evidence from China. J. Dev. Econ. 78 (1), 241-270. https://doi. $\operatorname{org} / 10.1016 / j . j d e v e c 0.2004 .08 .002$.

Deininger, K., Jin, S., 2008. Land sales and rental markets in transition: Evidence from rural Vietnam. Oxford Bull. Econ. Stat. 70 (1), 67-101.

De Janvry, A., Emerick, K., Gonzalez-Navarro, M., Sadoulet, E., 2015. Delinking land rights from land use: Certification and migration in Mexico. Am. Econ. Rev. 105 (10), 3125-3149.

Do, Q.T., Iyer, L., 2008. Land titling and rural transition in Vietnam. Econ. Dev. Cult. Change 56 (3), 531-579.

Duarte, M., Restuccia, D., 2010. The role of the structural transformation in aggregate productivity. Q. J. Econ. 125 (1), 129-173.

Dubois, P., 2002. Moral hazard, land fertility and sharecropping in a rural area of the Philippines. J. Dev. Econ. 68 (1), 35-64.

Feder, G., 1985. The relation between farm size and farm productivity: The role of family labor, supervision and credit constraints. J. Dev. Econ. 18 (2-3), 297-313.

Ghebru, H., Holden, S.T., 2014. Reverse-share-tenancy and agricultural efficiency: Farmlevel evidence from Ethiopia. J. Afr. Econ. 24 (1), 148-171.

Goldstein, M., Udry, C., 2008. The profits of power: Land rights and agricultural investment in Ghana. J. Polit. Econ. 116 (6), 981-1022.

Holden, S.T., Bezabih, M., 2008. Gender and land productivity on rented land in Ethiopia. In: Holden, Stein T., Otsuka, Keijiro, Place, Frank M. (Eds.), The Emergence of Land
Markets in Africa: Assessing the Impacts on Poverty, Equity and Efficiency. Routledge, New York, pp. 179-198.

Holden, S.T., Deininger, K., Ghebru, H., 2011. Tenure insecurity, gender, low-cost land certification and land rental market participation in Ethiopia. J. Devel. Stud. 47 (1), 31-47.

Holden, S.T., Otsuka, K., Place, F.M. (Eds.), 2010. The Emergence of Land Markets in Africa:" Impacts on Poverty, Equity, and Efficiency" Routledge, New York.

ILO, 2017. ILOSTAT Labour Statistics. International Labour Organization, Geneva.

Khai, L.D., Markussen, T., McCoy, S., Tarp, F., 2013. Access to land: market and nonmarket land transactions in rural Vietnam. In: Holden, S., Otsuka, K., Deininger, K. (Eds.), Land Tenure Reform in Asia and Africa: Assessing Impacts on Poverty and Natural Resource Management. Palgrave Macmillan, London, pp. 162-186.

Kimura, S., Otsuka, K., Sonobe, T., Rozelle, S., 2011. Efficiency of land allocation through tenancy markets: evidence from China. Econ. Dev. Cult. Change 59 (3), 485-510.

Kinghan, C., Newman, C., 2017. The rural non-farm economy. In: Tarp, F. (Ed.), Growth, Structural Transformation, and Rural Change in Viet Nam: A Rising Dragon on the Move. Oxford University Press, Oxford, pp. 91-113.

Macours, K., De Janvry, A., Sadoulet, E., 2010. Insecurity of property rights and social matching in the tenancy market. Eur. Econ. Rev. 54 (7), 880-899.

Markussen, T., 2017. Markets, property rights, and investment. In: Tarp, F. (Ed.), Growth, Structural Transformation, and Rural Change in Viet Nam: A Rising Dragon on the Move. Oxford University Press, Oxford, pp. 117-138.

Markussen, T., Tarp, F., 2014. Political connections and land-related investment in rural Vietnam. J. Dev. Econ. 110, 291-302.

Menon, N., van der Meulen Rodgers, Y., Kennedy, A.R., 2017. Land reform and welfare in vietnam: why gender of the land-rights holder matters. J. Int. Dev. 29 (4), 454-472.

Narciso, G., 2017. Labour and migration. In: Tarp, F. (Ed.), Growth, Structural Transformation, and Rural Change in Viet Nam: A Rising Dragon on the Move. Oxford University Press, Oxford, pp. 139-157.

Newman, C., Tarp, F., Van Den Broeck, K., 2015. Property rights and productivity: The case of joint land titling in Vietnam. Land Econ. 91 (1), 91-105.

Pingali, P.L., Xuan, V.T., 1992. Vietnam: Decollectivization and rice productivity growth. Econ. Dev. Cult. Change 40 (4), 697-718.

Promsopha, G., 2015. Land ownership as insurance and the market for land: A study in rural Vietnam. Land Econ. 91 (3), 460-478.

Ravallion, M., Van de Walle, D., 2008. Land in Transition: Reform and Poverty in Rura Vietnam. World Bank Publications. World Bank, Washington, DC.

Skoufias, E., 1995. Household resources, transaction costs, and adjustment through land tenancy. Land Econ. 42-56.

Tran, T.Q., 2001. Land Reform and Women's Property Rights in Vietnam. Center for Gender: Environment and Sustainable Development Working Paper, Hanoi.

Udry, C., 1996. Gender, agricultural production, and the theory of the household. J. Polit. Econ. 104 (5), 1010-1046.

World Bank, 2002. Promising Approaches to Engendering Development: Land Use Rights and Gender Equality in Vietnam. World Bank, Washington, DC.

World Bank, 2009. Vietnam Development Report 2010: Modern Institutions. The World Bank in Vietnam, Hanoi. 